\title{
Psychometric Properties of the Turkish Child and Adult Form of "Reading the Mind in the Eyes Test"
}

\author{
Alev Girli \\ Special Education Department, Dokuz Eylul University, İzmir, Turkey \\ Email: alev.girli@gmail.com \\ Received 11 June 2014; revised 6 July 2014; accepted 29 July 2014 \\ Copyright (C) 2014 by author and Scientific Research Publishing Inc. \\ This work is licensed under the Creative Commons Attribution International License (CC BY). \\ http://creativecommons.org/licenses/by/4.0/

(c) (i) Open Access

\begin{abstract}
The purpose of this study is to examine psychometric properties of "Reading the Mind in the Eyes Test" for both children and adult forms. Adult study group consists of 268 participants between the age of 18 - 60 (59.7\% female, $40.03 \%$ male). Children study group consists of 202 normally developed children and 33 children with autism between the ages of 6 to 16 . In the study, 42.1\% of children participants $(\mathrm{N}=99)$ were female and $57.9 \%$ were male $(\mathrm{N}=136)$. According to results, both forms have adequate internal consistency reliability (Cronbach Alpha value for adult form is 0.71 and for children form is $\mathbf{0 . 7 2}$ ). In children form, construct validity was examined in terms of age, gender and diagnosis and differentiation of this group were determined. Adults form is determined as a reliable and valid form for high school graduated individuals.
\end{abstract}

\section{Keywords}

Eyes Test, Theory of Mind, Autism, Advanced Mind Reading, Validity and Reliability

\section{Introduction}

Theory of mind can be defined in short as the ability to infer what others believe when faced with certain situations (Premack \& Woodruff, 1978). However, it covers a wide range such as expressing emotions, understanding jokes, developing empathy, understanding one's intent and knowing that different people have different perspectives (Howlin, Baron-Cohen, \& Hadwin, 1999; Miller, 2006). Development of the theory of mind occurs from understanding the desires and emotions towards understanding beliefs (Bartsch \& Wellman, 1995; Wellman, Philips, \& Rodrigez, 2000). It is known that precursors of the theory of mind are observed in babies with normal development from the time they start interacting with their environment; such as impressions of other 
people’s facial expressions (Meltzoff \& Moore, 1983), establishing common attention (Scaife \& Bruner, 1975), understanding and using other people’s emotions (Wellman, 1990).

Even though the studies carried out show that there are differences in the acquisition ages of theory of mind functions in different cultures and languages, it has been observed that in general children with normal development have an idea about the ideas, emotions and beliefs of others in short their "mental status" starting from the age of four (Wimmer \& Perner, 1983; Wellman, Cross, \& Watson, 2001). Children at this age can draw inferences regarding the mental status of the others or himself/herself with first degree false belief functions (Flavell \& Green 1999; Wimmer \& Perner, 1983). Whereas second degree false beliefs that include inferences regarding more than one mental state are acquired starting around the ages of six-seven (Baron-Cohen, Joliffe, Mortimore \&, Robertson, 1997a; Baron-Cohen, 2001; Flobbe, Verbrugge, Hendriks, \& Krämer, 2008). It has been shown in studies examining the theory of mind and the relevant factors in Turkish children (Aydin, Avc1, Granti, Sefer, Yaşa, \& Aksu-Koç, 2002; Bayramoğlu \& Hohenberg, 2007; Granti, 2004; Keçeli-Kaysılı \& Acarlar, 2011; Yağmurlu, Kazak-Berument, \& Çelimli, 2005) that similar results have been obtained.

The studies carried out have put forth that the theory of mind is very critical to develop social, emotional and communicative relationships with others (Perner, Frith, Leslie, \& Leekam, 1989; Watson, Nixon, Wilson, \& Capage, 1999). People with theory of mind insufficiency have difficulties in understanding the perspectives (Leslie, 1987), emotions, thoughts, beliefs and desires of others (Baron-Cohen, 1995). One of the theories that explain this insufficiency that has been observed in the social and communication skills of individuals with autism in recent years is the lack of theory of mind (Attwood, 2008; Baron-Cohen, Leslie, \& Frith, 1985). It has been shown in many studies that individuals with autism experience difficulties in understanding jokes, developing empathy, understanding and expressing emotions which are theory of mind skills that are very important in social life (Baron-Cohen, 2001; Howlin et al., 1999; Hale \& Tager-Flusberg, 2005; Tager-Flusberg, 1993).

Simple false belief tests were used to evaluate the theory of mind skills during the first years when the relationship between the theory of mind and autism was being established. Examples of first level false belief tests that measure mentalizing skills are transfer tests: Sally Ann (Wimmer \& Perner, 1983; Leslie \& Frith, 1988); unexpected content tests: “Smarties” test (Perner, Leekam, \& Wimmer, 1987), “Appearance-reality” test (Flavell, Everett, Croft, \& Flavell, 1981). Whereas some of the second level false belief tests are Chocolate bar test (Flobbe, Verbrugge, Hendriks, \& Krämer, 2008), Ice-cream truck test (Perner \& Wimmer, 1985). Children with normal development can pass the first level of these tests which measure the lower level mind reading skills between the ages of 4 - 6 and the second level between the ages of 7 - 9. However, development of the theory of mind continues after 7 - 9 ages and some of the tests that are used to evaluate advanced theory of mind skills are, “Strange Stories Test” (Happé, 1994), “Faux Pax” and “Eyes Test” (Baron-Cohen et al., 1997a).

It is observed that children with autism have a significant delay in their theory of mind abilities and that they can never reach the skill levels of their normally developing peers (Hale \& Tager-Flusberg, 2005). Whereas it has been shown in some studies that individuals with Asperger Syndrome (AS) and individuals with autism displaying high functionality can pass the second level false belief tests (Ozonoff, Pennington, \& Rogers, 1991; Ozonoff, Rogers, \& Pennington, 1991), however it has also been shown that these insufficiencies continue to be observed in advanced theory of mind tests (Baron-Cohen, Jolliffe, Mortimore, \& Robertson 1997a; Baron-Cohen, Wheelwright, \& Jolliffe, 1997b).

One of the tests that has been developed to measure advanced theory of mind skills is the "Reading the Mind in the Eyes Test” known also in short as the "Eyes Test” Baron-Cohen et al. (1997a). The test has been developed for adults and its first form consists of 25 eye photos among which the subjects are asked to select the emotion or thought in the eyes from among two choices. The adult form of the test has been revised in 2001 and another "Eyes Test" has also been prepared for children. The revised adult form of the test contains 36 whereas the child form contains 28 black and white photos and there are 4 choices (one target, three misleading) for each item. The Eyes Test aims to measure the theory of mind performance in addition to identifying emotions with its item structure (as in the cases of uncomfortable, pessimistic, flirtatious, hesitant) that refers to emotions that are more complex than primary emotions as well as thought processes (Baron-Cohen, Wheelwrigt, Scahill, Lawson, \& Spong, 2001b).

The revised adult version of the eyes test has been used to carry out many different studies on clinical groups such as schizophrenia, autism and normal population in addition to different cultures and languages. It has been put forth in these studies that the adult and child forms can distinguish these groups and that social cognition and "theory of mind” skills can be measured (Baron-Cohen, Wheelwright, Hill, Raste, \& Plumb, 2001a; Carroll \& 
Yung, 2006; Craig, Hatton, Craig, \& Bentall, 2004; Murphy, 2006; Domes, Heinrichs, Michel, Berger, \& Herpertz, 2007; Hallerbäck, Lugnegård, Hjärthag, \& Gillberge., 2009; Harkness, Sabbagh, Jacobson, Chowdrey, \& Chen, 2005; Kettle, O’Brien-Simpson, \& Allen, 2008; Lawrence, Shaw, Baker, Baron-Cohen, \& David, 2004; Losh \& Piven, 2006; Meyer \& Shean, 2006). Whereas the items expressing emotions have been simplified in some studies and the form has been rearranged by removing some items (Dziobek, Fleck, Kalbe, Rogers, Hassenstab, Brand, Kessler, Woike, Wolf, \& Convit, 2006, Dziobek, Rogers, Fleck, Hassenstab, Gold, Wolf, \& Convit 2005; Kelemen, Erdelyi, Pataki, Benedek, Janka, \& Keri, 2005; Kunihira, Senju, Dairoku, Wakabayashi, \& Hasegawa, 2006; Voracek \& Dressler, 2006).

The child form of the test has been translated into many languages such as Chinese, German, Spanish and Polish. However, even though these studies include information about the translation of the test, a study could not be found except the Swedish version (Hallerback et al., 2009) in which validity and reliability analyses have been carried out. The child form of the test has been used in the study carried out in Sweden but the participants have been selected from among university students. Researchers have made use of the Eyes test of Boren-Cohen et al. (2001a) during the study carried out by Peterson and Slaughter (2009) in Australia on a total of 87 participants consisting of children diagnosed with autism between the ages of 6 - 13, normal developing children in the same age group along with children in their early childhood period between $3-5$ as well as adults.

In the first study carried out on Turkish sample group Eyes Test adult form was applied to 43 bipolar diagnosed and 30 healthy individuals in addition to "hinting test", "face" and "emotion recognition tests" (Bora, Vahip, Gonul, Akdeniz, Alkan, Ogut, \& Eryavuz, 2005). Healthy individuals displayed a better performance in the Eyes Test in comparison with the bipolar diagnosed group $(F=7.73, p=0.007)$. It was determined that the Eyes Test displayed a statistically significant correlation with the Benton Face Recognition Test and Faces Test $(\mathrm{r}=$ 0.443, $\mathrm{p}<0.001)$, $(\mathrm{r}=0.542, \mathrm{p}<0.001)$. Another study has used the first 27 pictures of the revised form of the test (Baron-Cohen et al., 2001a) (Bora et al., 2005). The difference between the Eyes Test results of 25 patients with schizophrenia and bipolar disorder who were functioning well was determined to be significant $(\mathrm{p}<0.0001$, $\mathrm{F}=16.65$ ). Two more studies have been carried out in the same diagnosis groups on adult patients using this form and similar results have been obtained (Bora et al., 2008a, 2008b).

Yıldırım, Kaşar, Güdük, Ateş, Küçükparlak and Özalmete (2011) have examined the reliability of the Eyes Test. 2 items that were not selected were excluded from the pilot application of this study. This form was applied on 117 adults with normal development and the test was repeated on 70 selected people after two weeks. KR 20 value was determined as 0.69 for these 34 questions whereas the KR 20 value increased to 0.72 after two more items with low correct response ratio were excluded.

There is no study on the validity and reliability of the child form of the advanced theory of mind tests in our country. First and second level False Belief tests have been used in the small number of studies that evaluates the theory of mind skills of autistic children. It was determined in one of these studies which was carried out by Atasoy (2008) that children with autism display a lower performance in comparison to mentally insufficient children with normal development. Normal developing children and autistic children along with adolescents have been compared in the study carried out by Girli and Tekin (2010a) using first and second level false belief tests and another study (Girli \& Tekin, 2010b) carried out using the Eyes Test and Strange Stories test which are among the advanced theory of mind tests which have put forth similar results. The validity and reliability studies of the false belief tests have also been carried out by Girli and Tekin during their study (2010a).

It is thought that the child and adult form adaptation for "Reading the Mind in the Eyes" test which is widely used to evaluate the theory of minds abilities of autistic individuals will be carried out in this study thereby contributing to the literature. In addition, experts will be able to use the Eyes Test as an auxiliary evaluation tool during the diagnosis stage of children and young people with autism. Whereas instructors who work with autistic individuals can make use of the Eyes Test as an evaluation tool while planning social skill studies. The objective of this study is to examine the psychometric properties of the adult and child form of the "Reading the Mind in the Eyes Test” which is used to test the advanced theory of mind skills.

\section{Method}

This study is a validity and reliability study carried out on a Turkish sample group using the "Reading the Mind in the Eyes Test" known in short as the "Eyes Test" developed by Baron-Cohen et al. the adult form of which was revised in 2001 as well as the child form was developed in the same year. All photographs have been standardized in a single dimension $(15 \times 10 \mathrm{~cm})$ and all are black and white. In addition all have been selected to 
depict the same region of the face (from the middle of the nose up to the eyebrows). There is a word that expresses the emotion in each of the four corners of the photographs. The locations of the four words have been selected randomly for each item. Each question has only one single correct answer. The subject is asked to select the word from among the 4 which he/she thinks best depicts the emotion displayed in the photograph. There is practice page in the beginning of each form to ensure that the subject fully understands the application.

There are 36 eye photos in the revised version of the adult form and there are 4 options (one target, three misleading) for all. Each photo is shown to the subject for 3 seconds after which he/she is asked to select the word that best expresses the emotion displayed in the photo. Every correct reply is worth one point and the maximum score of the test is 36 (Figure 1).

The child form consists of a total of 28 photos 25 of which have been selected from the adult form with an addition of three new photos. The Eyes Test contains cognitive status terms that are emotional as well as not related with emotions such as insolent, suspicious, anxious etc. However, the words used in the child form are simpler so that children can understand the emotional and cognitive status expressions (Figure 1). 1 point is given for each correct answer in the evaluations. The maximum score of the test is 28. Getting a score of nine or above has been determined as the indication that the responses are not based on luck (Baron-Cohen et al., 2001a). High scores indicate that the social cognition and theory of mind skills are good.

\subsection{Turkish Translation of the Test}

The child and adult forms of the test have been translated independently from English into Turkish by three experts consisting of a researcher, an expert instructor and an expert with developmental psychology Ph.D. It was not always possible to find a single word expression for similar emotions for which there are separate words in the English language. That is why some emotions were expressed using two-three words. The language development properties of the children based on their ages were taken into account during the translation process and simpler words were selected for the child form. Three translations were brought together for each of the two forms after which corrections were made and a "temporary test" for that form was compiled. Back-translation method (Karasar, 1995) was used for the "linguistic equivalence" study and the prepared tests were translated back to English by a professional translator. The two English tests were compared and no incomprehensibility was observed. The final Turkish tests were used in the study.

The photos in the original tests were used in the child form by printing on similar dimension cardboards. Whereas in the adult form the original photos were arranged as slides with the same dimensions. The dictionary which contains the words in the original adult form of the test was translated using the same method.

\subsection{Study Group}

\subsubsection{Adult Study Group}

The adult study group consisted of a total of 268 volunteers who were students and employees at the Dokuz Eylül University Faculty of Education. The ages of the participants varied between 18 and 60, 160 (59.7\%) of which are female and 108 (40.03\%) of which are male.

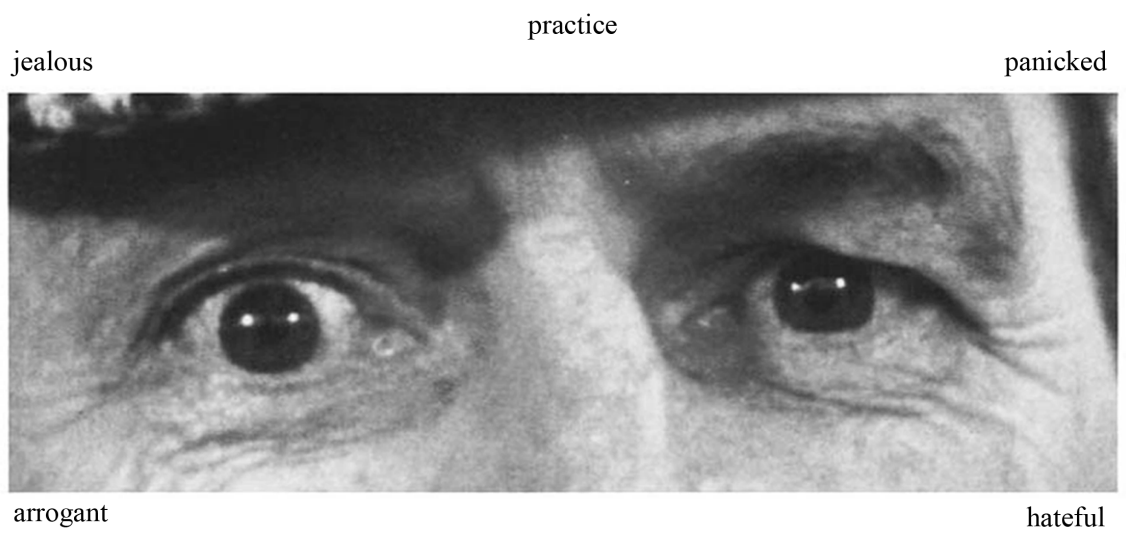

Figure 1. The Eyes Test. 


\subsubsection{Child Study Group}

The criterion sampling method used by the units that meet the determined criterion (Büyüköztürk, Kilıç-Çakmak, Akgün, Karadeniz, \& Demirel, 2008) was used to form the child group. The eyes test is applied to children of age 6 and above when the first and second stages of the theory of mind development have been completed. That is why the participants consisted of a total of 235 children between the ages of 6 and 16 who meet the criterion listed above 202 of whom show normal development and 33 of whom have autism diagnosis. 99 (42.1\%) of the participants are female and 136 (57.9\%) are male. Children with normal development and children with autism reside in neighborhoods where middle to upper middle socio-economic families reside and they attend the elementary schools or private schools in their neighborhoods. The criterion used for the selection of the participants have been given below:

For participants who display normal development; a-having no diagnosis regarding a disability area. Guidance services of the schools were contacted for these criteria and children who had a diagnosis or who were thought to be in a risk group were not included in the study, b-passing the first and second level false belief tests. Children who might have various limitations were excluded with this test and these tests also functioned as control test.

For participants with autism: 1) to be diagnosed by expert doctors in the pediatric psychology departments of university hospitals; 2) passing the first and second level false belief tests; 3) developmental age measured via PEP-R test; having a verbal and cognitive field age of above six.

\subsubsection{Prerequisite Tests for Children with Autism}

"Sally-Anne Test" and "Unexpected Content Test" from the first level false belief tests and "Ice Cream Truck Test" and "Chocolate Test" from the second level false belief tests were used as well in addition to PsychoEducational Profile (PEP-R) for developmental evaluation.

1) Psycho-Educational Profile Revision (PEP-R): The form of "Psycho-Educational Profile Scale" revised by Schopler, Reichler, Bashford, Lansing and Marcus (1990) was used in this study. The test evaluates the developmental levels of children with autism in seven areas as well as their autistic behaviors. Girli, Atasoy and Mutlu (2003) translated the test into Turkish and carried out the reliability and validity studies. The developmental field and behavioral field Cronbach Alpha values were determined as 0.88 and 0.97 respectively. Similar scale validity was examined with AGTE (Ankara Gelişim Tarama Envanteri) in the developmental field $(\mathrm{r}=$ $0.81)$ and Ritvo-Freeman Scale $(r=0.68)$ in the behavioral field. PEP-R has been evaluated as a reliable and valid test that can be used in Turkey (Girli et al., 2003).

2) Sally-Anne Test: It is among the 1st level "transfer" false belief tests (Wimmer \& Perner, 1983). Kuder-Richardson reliability coefficient has been calculated as KR-21 $=0.78$ in the study carried out by Girli and Tekin (2010). 80.3\% of the children displaying normal development have passed the test whereas $19.7 \%$ have failed and $28.6 \%$ of the children with autism have passed the test whereas $71.6 \%$ have failed. Discriminant validity has been examined and it has been determined that the Sally-Anne test distinguishes children with autism from ND (normal development) children $\left(\chi^{2}=23.094\right.$, $\left.\mathrm{df}=1, \mathrm{p}=0.000\right)(\mathrm{p}<0.0001)$.

3) Smarties test: It is among the 1 st level false belief tests. It has been developed by Perner et al. (1987). Reliability has been calculated as KR-21 $=0.82$ in the study carried out on Turkish sample group. 93.9\% of the children displaying typical development have passed the test and $6.1 \%$ have failed whereas $47.9 \%$ of children with autism have passed the test and $57.1 \%$ have failed. Similar to international studies, it has been determined that it distinguishes children with autism from ND (normal development) children $\left(\chi^{2}=30.627, \mathrm{df}=1, \mathrm{p}=\right.$ 0.000) (p < 0.0001) (Girli \& Tekin, 2010).

4) Ice Cream Truck Test: It has been developed by Perner and Wimmer (1985). The reliability of the Turkish form has been calculated as KR-21 $=0.84 .63 .6 \%$ of the children displaying typical development have passed the test whereas 36.4 have failed and 7.1 of the children with autism have passed the test whereas $92.9 \%$ have failed. It has been determined that the Ice-cream truck test $\left(\chi^{2}=25.200, \mathrm{df}=1, \mathrm{p}=0.000\right)$ distinguishes children with autism from ND children ( $<$ 0.0001) (Girli \& Tekin, 2010).

5) Chocolate bar task: It has been developed by Flobbe et al. (2008). The reliability of the Turkish form has been carried out (Girli \& Tekin 2010). The reliability value has been calculated as KR-21 $=0.84 .74 .2 \%$ of the children displaying typical development have passed the test whereas $25.8 \%$ have passed and 14.3 of the children with autism have passed the test and 85.7 have failed. It has been determined that this test distinguishes children with autism from ND children $\left(\chi^{2}=28.737, \mathrm{df}=1, \mathrm{p}=0.000\right)(\mathrm{p}<0.0001)$. 


\subsection{Procedure}

\subsubsection{Application of the Child Eye Test}

The tests have been applied at the schools of the children in a silent classroom or in the guidance room by the researcher. A short conversation of a few minutes was carried out prior to the test in order to meet the child and ensure that he/she understands the tests. First, 1st and 2nd level false belief tests were applied which lasted for 25 - 30 minutes. Afterwards, in accordance with the application directive of the Eyes Test, a practice test was applied and the child was asked if he/she has any questions or not; the relevant explanations were made to the children who asked questions. Each application lasted for about 5 - 10 minutes. The prerequisite tests of children with autism have been completed in 35 - 45 minutes whereas the "Eyes Test” has lasted 10 - 15 minutes.

\subsubsection{Application of the Adult Eye Test}

The test was applied in a computer environment as was the case in the original form of the test. The photos in the slides were arranged to be displayed for 3 seconds, however the choices remained on the screen after the images were removed. The applications were carried out individually in a silent environment. The applier has asked the question, "which do you think best describes what this person thinks or feels?”. The applier passed from item to item and recorded the replies in order to ensure that the participants focus on the test. The dictionary containing the definitions of the words used in the test was kept on hand. Each application lasted for about 10 - 15 minutes on average.

\subsubsection{Data Analysis}

SPSS 15.0 software was used for data analysis. The methods of the study in which the psychometric properties of the original test have been examined were followed in this study. First, the distribution of the test scores was examined. Comparisons were made among groups in terms of diagnosis, gender and age in construct validity analysis. Item-score correlations were calculated to test internal validity. Cronbach Alpha internal consistency coefficient and item-total score reliability have been calculated for reliability study. In addition, the ratios of the correct responses for each of the items have been examined.

\section{Results}

It was determined by Kolmogrov-Smirnov test that the test scores of both children and adult eye tests. Accordingly, it has been determined that the eyes test score average for children is $(X=16.50)$ and that the test scores display normal distribution $(\mathrm{Z}=1.241, \mathrm{p}=0.067>0.05)$; whereas it has also been determined that the eyes test score average for adults is $(X=21.59)$ and that it also displays normal distribution $(Z=1.207, p=0.108>0.05)$.

\subsection{Reliability Data}

The total score reliability values of both forms have been calculated and the Cronbach alpha value for the child form was determined as 0.72 whereas it was determined as 0.71 for the adult form. The alpha internal consistency coefficient has been calculated for each form and the child form has been given in (Table 1 ) whereas the adult form has been given in (Table 2).

It was determined that the Cronbach alpha internal consistency coefficients when each item is excluded vary between 0.69 and 0.73 for the child form and between 0.69 and 0.71 for the adult form. According to Özdamar (1999), the scale is not reliable if the alpha coefficient is between 0 and 0.40 and it has a low reliability if the value is between 0.40 and 0.60 and the scale is mostly reliable if the value is between 0.60 and 0.80 . Alpha coefficient values of 0.80 and above are evaluated as highly reliable. Accordingly, it can be stated that the reliability values of both scales are sufficient. The item total correlation values of both forms of the test show that the internal validity of the scale is at a sufficient level.

\subsection{Distribution of Responses}

When the correct response ratios are examined, it is observed that the correct response ratio varies between $30.2 \%$ and $85.1 \%$ for the child form (Table 3) and between $31 \%$ and $82.5 \%$ for the adult form (Table 4).

When the selection ratios of the false items in the tables are examined, it can be said that the false items are strong and thus that these items are difficult. Similar emotions are tested with more than one photo in each form 
Table 1. Item total correlations and alpha coefficient analysis results for the child form.

\begin{tabular}{|c|c|c|c|c|}
\hline Items & $\begin{array}{l}\text { Scale Average when } \\
\text { Item is Excluded }\end{array}$ & $\begin{array}{l}\text { Scale Variance when } \\
\text { Item is Excluded }\end{array}$ & $\begin{array}{c}\text { Corrected } \\
\text { Item-Total Correlation }\end{array}$ & $\begin{array}{l}\text { Cronbach Alpha } \\
\text { when Item is Excluded }\end{array}$ \\
\hline 1 & 15.8894 & 18.449 & 0.167 & 0.716 \\
\hline 2 & 15.7489 & 18.334 & 0.234 & 0.711 \\
\hline 3 & 16.2000 & 18.015 & 0.297 & 0.707 \\
\hline 4 & 15.6596 & 18.448 & 0.257 & 0.710 \\
\hline 5 & 16.1532 & 18.318 & 0.206 & 0.713 \\
\hline 6 & 15.9957 & 18.269 & 0.203 & 0.713 \\
\hline 7 & 15.6936 & 18.145 & 0.324 & 0.706 \\
\hline 8 & 15.7915 & 17.627 & 0.407 & 0.699 \\
\hline 9 & 15.7489 & 18.830 & 0.099 & 0.720 \\
\hline 10 & 15.9404 & 18.116 & 0.242 & 0.711 \\
\hline 11 & 15.9149 & 17.318 & 0.445 & 0.695 \\
\hline 12 & 15.7745 & 18.295 & 0.234 & 0.711 \\
\hline 13 & 16.0681 & 17.970 & 0.278 & 0.708 \\
\hline 14 & 15.9319 & 17.713 & 0.342 & 0.703 \\
\hline 15 & 16.0426 & 18.571 & 0.132 & 0.719 \\
\hline 16 & 15.8298 & 18.065 & 0.276 & 0.708 \\
\hline 17 & 15.7404 & 18.330 & 0.240 & 0.711 \\
\hline 18 & 15.7234 & 17.833 & 0.393 & 0.701 \\
\hline 19 & 16.0255 & 18.820 & 0.073 & 0.723 \\
\hline 20 & 15.6511 & 18.203 & 0.348 & 0.705 \\
\hline 21 & 15.7617 & 17.704 & 0.403 & 0.700 \\
\hline 22 & 15.9234 & 18.080 & 0.253 & 0.710 \\
\hline 23 & 15.7489 & 17.633 & 0.432 & 0.698 \\
\hline 24 & 16.0298 & 18.140 & 0.234 & 0.711 \\
\hline 25 & 16.1745 & 18.666 & 0.123 & 0.719 \\
\hline 26 & 16.1915 & 19.489 & 0.077 & 0.732 \\
\hline 27 & 16.0340 & 18.418 & 0.168 & 0.716 \\
\hline 28 & 16.1702 & 18.253 & 0.226 & 0.712 \\
\hline
\end{tabular}

Table 2. Item total correlations and Cronbach alpha analysis results for the adult form.

\begin{tabular}{ccccc}
\hline Items & $\begin{array}{c}\text { Scale Average when } \\
\text { Item is Excluded }\end{array}$ & $\begin{array}{c}\text { Scale Variance when } \\
\text { Item is Excluded }\end{array}$ & $\begin{array}{c}\text { Corrected } \\
\text { Item-Total Correlation }\end{array}$ & $\begin{array}{c}\text { Cronbach Alpha when } \\
\text { Item is Excluded }\end{array}$ \\
\hline 1 & 21.2575 & 24.956 & 0.075 & 0.709 \\
2 & 20.7724 & 24.873 & 0.137 & 0.705 \\
3 & 21.0522 & 25.128 & 0.032 & 0.712 \\
\hline
\end{tabular}




\section{Continued}

\begin{tabular}{|c|c|c|c|c|}
\hline 4 & 20.9888 & 24.476 & 0.170 & 0.704 \\
\hline 5 & 20.9664 & 24.849 & 0.094 & 0.708 \\
\hline 6 & 20.9179 & 24.930 & 0.083 & 0.709 \\
\hline 7 & 21.1455 & 24.904 & 0.077 & 0.710 \\
\hline 8 & 20.8619 & 23.985 & 0.313 & 0.695 \\
\hline 9 & 20.7799 & 24.464 & 0.241 & 0.700 \\
\hline 10 & 20.9478 & 24.477 & 0.176 & 0.703 \\
\hline 11 & 20.8470 & 24.190 & 0.272 & 0.697 \\
\hline 12 & 21.0261 & 24.310 & 0.201 & 0.702 \\
\hline 13 & 20.9104 & 24.052 & 0.278 & 0.697 \\
\hline 14 & 21.0336 & 23.808 & 0.306 & 0.695 \\
\hline 15 & 20.7836 & 23.818 & 0.411 & 0.691 \\
\hline 16 & 20.8731 & 24.134 & 0.273 & 0.697 \\
\hline 17 & 21.0187 & 25.000 & 0.059 & 0.711 \\
\hline 18 & 20.8619 & 23.962 & 0.319 & 0.695 \\
\hline 19 & 21.1866 & 23.838 & 0.303 & 0.695 \\
\hline 20 & 20.9328 & 24.175 & 0.245 & 0.699 \\
\hline 21 & 21.0634 & 24.464 & 0.167 & 0.704 \\
\hline 22 & 20.9254 & 23.410 & 0.419 & 0.688 \\
\hline 23 & 21.2500 & 24.555 & 0.160 & 0.704 \\
\hline 24 & 21.0522 & 23.945 & 0.275 & 0.697 \\
\hline 25 & 21.1791 & 25.031 & 0.053 & 0.711 \\
\hline 26 & 21.0784 & 23.938 & 0.275 & 0.697 \\
\hline 27 & 21.0522 & 23.645 & 0.339 & 0.692 \\
\hline 28 & 21.2351 & 23.806 & 0.319 & 0.694 \\
\hline 29 & 20.9776 & 24.029 & 0.267 & 0.697 \\
\hline 30 & 20.8246 & 24.355 & 0.243 & 0.699 \\
\hline 31 & 20.9515 & 24.458 & 0.179 & 0.703 \\
\hline 32 & 21.0634 & 24.224 & 0.216 & 0.701 \\
\hline 33 & 20.9664 & 24.212 & 0.229 & 0.700 \\
\hline 34 & 20.9067 & 24.122 & 0.264 & 0.698 \\
\hline 35 & 21.2873 & 25.074 & 0.054 & 0.710 \\
\hline 36 & 20.9179 & 24.660 & 0.142 & 0.705 \\
\hline
\end{tabular}


Table 3. Distribution of the correct response ratio of the child form (Correct responses have been shown in dark color).

\begin{tabular}{|c|c|c|c|c|}
\hline Item & $\mathrm{A} \%$ & B\% & C\% & D \% \\
\hline 1 & 5.1 & 10.6 & 61.3 & 23 \\
\hline 2 & 3.8 & 5.5 & 15.3 & 75.3 \\
\hline 3 & 30.2 & 19.1 & 9.4 & 41.3 \\
\hline 4 & 3 & 84.3 & 8.1 & 4.7 \\
\hline 5 & 37.9 & 34.9 & 10.2 & 17 \\
\hline 6 & 5.5 & 5.5 & 50.6 & 38.3 \\
\hline 7 & 4.3 & 4.3 & 80.9 & 10.6 \\
\hline 8 & 71.1 & 4.3 & 2.1 & 22.6 \\
\hline 9 & 10.6 & 1.3 & 12.8 & 75.3 \\
\hline 10 & 11.1 & 19.6 & 56.2 & 13.2 \\
\hline 11 & 7.2 & 58.7 & 7.2 & 26.8 \\
\hline 12 & 19.6 & 2.1 & 5.5 & 72.8 \\
\hline 13 & 43.4 & 22.6 & 21.3 & 12.8 \\
\hline 14 & 13.6 & 57 & 17.4 & 11.9 \\
\hline 15 & 46 & 18.7 & 12.8 & 22.6 \\
\hline 16 & 67.2 & 3.8 & 14.9 & 14 \\
\hline 17 & 8.9 & 7.7 & 7.2 & 76.2 \\
\hline 18 & 77.9 & 6.4 & 9.8 & 6 \\
\hline 19 & 5.5 & 42.6 & 4.3 & 47.7 \\
\hline 20 & 1.7 & 6.4 & 85.1 & 6.8 \\
\hline 21 & 74 & 5.1 & 11.1 & 9.8 \\
\hline 22 & 15.7 & 16.2 & 10.2 & 57.9 \\
\hline 23 & 8.1 & 75.3 & 7.2 & 9.4 \\
\hline 24 & 47.2 & 18.7 & 28.1 & 6 \\
\hline 25 & 14.9 & 37 & 15.3 & 32.8 \\
\hline 26 & 7.2 & 9.4 & 31.1 & 52.3 \\
\hline 27 & 22.1 & 11.1 & 46.8 & 20 \\
\hline 28 & 21.7 & 11.5 & 32.2 & 33.6 \\
\hline
\end{tabular}

Table 4. Distribution of the correct response ratio of the adult form (Correct responses have been shown in dark color).

\begin{tabular}{ccccc}
\hline Item & A\% & B\% & C\% & D\% \\
\hline 1 & $\mathbf{3 4}$ & 29.9 & 26.5 & 9.7 \\
2 & 5.6 & $\mathbf{8 2 . 5}$ & 4.1 & 7.8 \\
3 & 27.6 & 3.4 & $\mathbf{5 4 . 5}$ & 14.6 \\
4 & 18.3 & $\mathbf{6 0 . 8}$ & 7.1 & 13.8 \\
5 & 7.1 & 25.7 & $\mathbf{6 3 . 1}$ & 4.1 \\
7 & 4.1 & $\mathbf{6 7 . 9}$ & 7.8 & 20.1 \\
\hline
\end{tabular}




\begin{tabular}{|c|c|c|c|c|}
\hline Continued & & & & \\
\hline 8 & 73.5 & 5.6 & 14.9 & 6 \\
\hline 9 & 7.8 & 6 & 4.5 & 81.7 \\
\hline 10 & 64.9 & 15.7 & 10.8 & 8.6 \\
\hline 11 & 9.7 & 9.7 & 75 & 5.6 \\
\hline 12 & 27.6 & 7.8 & 57.1 & 7.5 \\
\hline 13 & 10.8 & 68.7 & 6.3 & 14.2 \\
\hline 14 & 13.1 & 12.7 & 17.9 & 56.3 \\
\hline 15 & 81.3 & 6.7 & 7.1 & 4.9 \\
\hline 16 & 9.3 & 72.4 & 6.3 & 11.9 \\
\hline 17 & 57.8 & 27.2 & 2.2 & 12.7 \\
\hline 18 & 73.5 & 11.9 & 7.8 & 6.7 \\
\hline 19 & 20.1 & 25.4 & 13.4 & 41 \\
\hline 20 & 8.6 & 66.4 & 20.1 & 4.9 \\
\hline 21 & 17.5 & 53.4 & 24.3 & 4.9 \\
\hline 22 & 67.2 & 8.6 & 10.4 & 13.8 \\
\hline 23 & 12.3 & 8.6 & 34.7 & 44.4 \\
\hline 24 & 54.5 & 19 & 9 & 17.5 \\
\hline 25 & 3.4 & 32.8 & 22 & 41.8 \\
\hline 26 & 8.6 & 6.7 & 51.9 & 32.8 \\
\hline 27 & 9.3 & 54.5 & 17.9 & 18.3 \\
\hline 28 & 36.2 & 30.6 & 11.9 & 21.3 \\
\hline 29 & 6 & 24.3 & 7.8 & 61.9 \\
\hline 30 & 6.3 & 77.2 & 9.7 & 6.7 \\
\hline 31 & 9.3 & 64.6 & 11.6 & 14.6 \\
\hline 32 & 53.4 & 8.2 & 17.5 & 20.9 \\
\hline 33 & 4.1 & 19.8 & 13.1 & 63.1 \\
\hline 34 & 9.3 & 13.4 & 69 & 8.2 \\
\hline 35 & 44.8 & 31 & 12.7 & 11.6 \\
\hline 36 & 7.1 & 6.7 & 67.9 & 18.3 \\
\hline
\end{tabular}

and the correct responses are presented with false responses of varying difficulty levels. When both tables are examined, it is observed that the items are distributed across various difficulty levels.

\subsection{Validity Analyses}

The correlation between the scores of the items and the total test score (item-score correlation) has been examined in order to test internal validity. When the acquired data (Table 1 and Table 2) are examined, it is seen that both forms are at sufficient levels in terms of internal validity. It was examined whether the scores differ according to diagnosis, gender and age in order to test the construct validity. 


\subsection{According to Diagnosis}

$\mathrm{T}$ test was applied on unrelated samples in order to examine whether the test performances of participants with autism and others differ in the child form (Table 5).

As can be seen in Table 5, the score average of children with normal development $(X=17.06)$ is higher in comparison with that of the children with autism $(X=13.06)$. It has been determined that the Eyes Test performances of the children display a statistically significant difference [t(233) $=5.09, \mathrm{p}=0.000<0.05]$ according to diagnosis.

Comparison based on diagnosis could not be carried out for the adult form since there was no adult participant diagnosed with autism.

\subsection{According to Gender}

$\mathrm{T}$ test was used to examine whether the performance of the Eyes Test in the child form varied according to gender or not (Table 6).

It was determined that the score average of girls $(X=17.70)$ is higher than that of boys $(X=16.48)$ and that this difference was statistically significant $[\mathrm{t}(200)=2.14, \mathrm{p}=0.033<0.05]$. It is observed that girls are more successful.

The score average for Adult Eyes Test of female participants has been calculated as $\mathrm{X}=22.05$ whereas that of the male participants has been calculated as $X=20.92$. Even though the score average of female participants was greater than that of the male participants, a statistically significant difference was not determined between the two groups $[\mathrm{t}(266)=1.79, \mathrm{p}=0.074]$.

\subsection{According to Age}

Finally, it was examined whether there was a difference between the Eyes Test scores of children according to age. The participants were distributed into three groups according to age based on their theory of mind levels. Accordingly, the first group consisted of participants at the ages of 6, 7 and 8, the second group consisted of participants between the ages of 9 - 10 and the third group consisted of participants with ages of 11 and above. The score graph of the participants according to age groups has been shown in (Figure 2).

ANOVE test was applied to determine whether there was a difference between the Eyes Test score averages of the participants according to age groups. Accordingly, it has been observed that the Eyes Test performance displays a statistically significant difference according to age $[F=9.008, p=0.000<0.05]$. Tukey and Bonferroni of the Post-Hoc tests have been applied in order to determine which groups cause the performance difference between the age groups. The Bonferroni Test results can be seen in Table 7 and show similarities with the Tukey Test results.

Bonferroni test results put forth that the scores of the first group containing participants between the ages of 6 - 8 are lower in comparison with those of the second group $(p=0.003<0.05)$ and the third group $(p=0.000<$ $0.05)$ at a statistically significant level. A statistically significant difference $(p=0.003<0.05)$ was determined

Table 5. T-test results for unrelated samples of child form participants according to diagnosis.

\begin{tabular}{cccccc}
\hline Diagnosis & $\mathrm{X}$ & $\mathrm{S}$ & $\mathrm{Sd}$ & $\mathrm{t}$ & $\mathrm{p}$ \\
\hline ND & 17.06 & 4.10 & 233 & 5.09 & 0.000 \\
Autism & 13.06 & 4.66 & & & \\
\hline
\end{tabular}

$\mathrm{p}<0.01$.

Table 6. T-test results for unrelated samples of child form ND participants according to gender.

\begin{tabular}{cccccc}
\hline Gender & $\mathrm{X}$ & $\mathrm{S}$ & $\mathrm{Sd}$ & $\mathrm{t}$ & $\mathrm{p}$ \\
\hline Girls & 17.70 & 3.91 & 200 & 2.14 & 0.033 \\
Boys & 16.48 & 4.20 & & & \\
\hline
\end{tabular}

$\mathrm{p}<0.05$. 


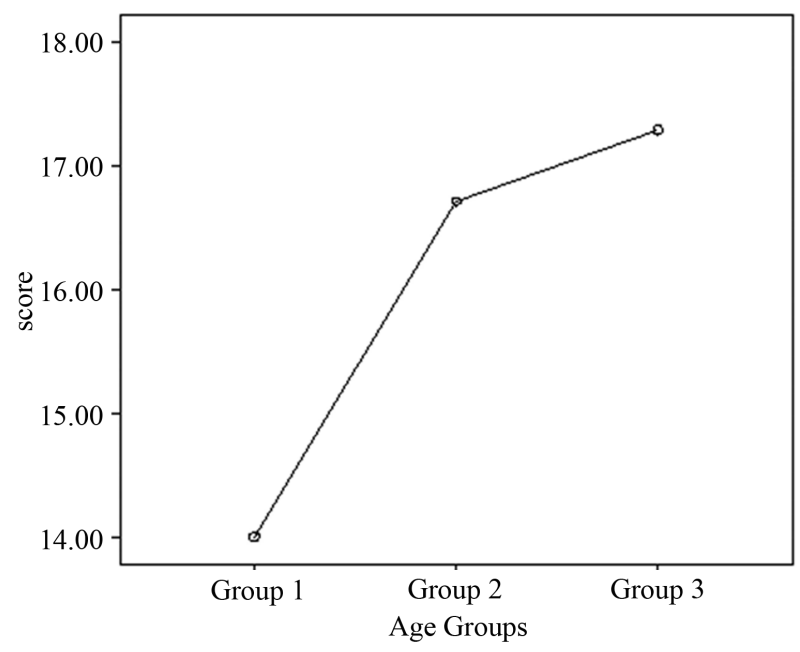

Figure 2. Score increase graph of the child form participants according to age groups.

Table 7. Bonferroni test results of child form normal developing child participants according to age groups.

\begin{tabular}{ccccccc}
\hline \multicolumn{2}{c}{$\begin{array}{c}\text { Bonferroni } \\
\text { Group and Age }\end{array}$} & Average Difference & $\begin{array}{c}\text { Standard } \\
\text { Error }\end{array}$ & $p$ & \multicolumn{2}{c}{$95 \%$ Reliability Interval } \\
\cline { 6 - 7 } $1(6-8)$ & 2 & $-2.71264^{*}$ & 0.86094 & 0.003 & -4.6586 & -0.7667 \\
& 3 & $-3.28972^{*}$ & 0.78241 & 0.000 & -5.1765 & -1.4030 \\
$2(9-10)$ & 1 & $-2.71264^{*}$ & 0.80694 & 0.003 & 0.7667 & 4.6586 \\
& 3 & -0.57708 & 0.61495 & 1.000 & -2.0600 & 0.9058 \\
$3(11>)$ & 1 & $-3.28972^{*}$ & 0.78241 & 0.000 & 1.4030 & 5.1765 \\
& 2 & 0.57708 & 0.61495 & 1.000 & 0.9058 & 2.0600 \\
\hline
\end{tabular}

between the scores of the second group containing participants aged 9 and 10, whereas no statistically significant difference was determined with the third group $(p=1.000>0.05)$. Finally, when the participants in the third group aged 11 and above are examined, a statistically significant difference was determined with the first group $(\mathrm{p}=0.000<0.05)$ and no statistically significant difference was determined with the second group $(\mathrm{p}=$ $1.000>0.05$ ). In other words, it was determined that the children in the smallest age group (6 - 8 years of age) displayed a lower performance in comparison with the older children (9 and above) who comprise the second and third groups.

\section{Discussion}

In this study, the reliability and validity of the Turkish adaptation of the child and adult forms of the Eyes Test (Baron-Cohen et al., 2001a) which is accepted as an advanced theory of mind test used to test the theory of mind skills have been examined with a group consisting of 235 children and 268 adults.

It is accepted for a test reliability that its Cronbach alpha reliability values and item-total Cronbach alpha internal consistency coefficients be over 0.70 (Büyüköztürk, et al. 2008). It can be said that both the child and adults forms of the eyes test are reliable since the reliability level and item-score internal consistency coefficients are above this level. It is observed that this result is in accordance $\mathrm{w}+$ ith the study results carried out in Turkey (Yıldırım et al., 2011), with the study carried out using the original form (Baron-Cohen et al., 2001a) and other studies that were reached (Hallerback et al., 2009; Peterson \& Slaughter, 2009).

When the test choice selection ratios in the adult form are examined, it was observed that the correct answer ratios for 29 of the 36 items were above $50 \%$ and that the correct answer ratios for the 23rd and 35th items were lower than those of the false answers. The correct answer in the 23rd item which is "resisting" (34.4\%) was selected less in comparison with "in curiosity" option (44.4\%) which was one of the false answers; the correct answer in the 35th item which is "angry" (31\%) was selected less in comparison with the false answer "wrapped 
up in” (44.8\%). A similar case was observed in the study carried out by (Y1ldırım et al., 2011) for the 19th and 21st items and these items were removed from the test. However, since the Cronbach alpha values of this test and these items were sufficient in this study, the items were not removed from the test.

The correct answer in the 3rd item of the child form is "in a friendly manner" option (30.2\%) however the participants have selected the option "anxious" more (41.3\%). Whereas the correct answer of the 26th item "angry" was selected with a ratio of (31.1\%), the false response "regretful" was selected more (52.3\%). This can be explained by cultural differences. When the results of the study carried out in Sweden (Hallerback et al., 2009) are examined, similar issues are observed for some items. It is observed that in some cultures the same mimic can be expressed by using another emotion word. For example, a study carried out to examine the effects of language and culture on emotion recognition studies has put forth that British participants have a tendency to interpret the "anger" expression as "surprise" (Carroll \& Russell, 1996; cit. Y1ldırım et al., 2011). Experts who have carried out emotion recognition studies in different cultures for long period of time (Biehl, Matsumoto, Ekman, Hearn, Heider, Kudoh, \& Ton, 1997; Ekman, 1984, 1994; Ekman \& Friesen, 1986) have put forth many proofs that people from different cultures can define the expressions for seven basic emotions which are happiness, surprise, anger, disgust, fear, contempt and sadness. However, cultural differences were still observed in defining some emotions; for instance a study comparing six countries put forth that Japanese receive worse scores than Americans, Vietnamese and Polish in recognizing anger whereas the Vietnamese get worse results in recognizing disgust in comparison with other countries. It is thought that this is due to cultural differences in emotional expression (cit. Gerrig \& Zimbardo, 2012). The fact that false answers were selected more in a study carried out in two different languages increases the opportunity to explain as the effect of language or culture.

It was observed in the first reliability study carried out using the Adult Eyes Test Turkish form (Y1ldırım et al., 2011) that some answers were not selected. There is no answer in this study which has not been selected. A single word in Turkish could not be found during the translation process for some of the emotions in English and the original meaning was tried to be given with a few words. The reason for this might be the fact that the richness of the words used to express certain emotions caries from culture to culture. Whereas there is only one word to express basic emotions such as happiness, sadness or anger; there might be no word to express complex emotions. However, the fact that there is no answer that has not been selected can be accepted as success in finding the Turkish expressions of the original words.

When the gender analysis of the participants of the Adult Eyes test is made, a statistically significant difference was not determined between the scores of female and male participants [t(266) $=1.79, \mathrm{p}=0.074]$. Even though the result was not statistically significant; the score averages of the female participants were determined to be higher in comparison with those of the male participants. It has been determined in the original study of the test that female participants display a higher performance at a statistically significant manner (Baron-Cohen et al., 2001a). A statistically significant difference was not determined between the genders of participants with higher education levels in the study carried out in Turkey (Yildirım et al., 2011) whereas it was observed that male participants displayed a higher performance in comparison with female participants in the lower education level group. When it is considered that all of the participants of this study are either university students or university graduates, the fact that there is no difference between the scores based on gender can be explained with the high level of education and this result is in accordance with the results of the study carried out by Yildırim et al. (2011).

The results of the original child form and the Turkish form are in accordance. Accordingly, the comparison carried out between the original form based on diagnosis and age has put forth that individuals with autism or Asperger Syndrome display a lower performance in comparison with individuals with normal development (Baron-Cohen et. al., 2001a; Baron-Cohen et. al., 2001b). This result has been repeated in the Turkish form of the test as well and the children with normal development have displayed a higher performance in comparison to children with autism. This result shows that the test developed by Baron-Cohen et al., (2001a) to put forth the differences between children with autism and their peers with normal development in terms of advanced theory of mind skills can be used reliably in different cultures (Carroll \& Yung, 2006; Craig et al., 2004; Murphy, 2006; Domes et al., 2007; Hallerback et al., 2009; Harkness et al., 2005; Kettle et al., 2008; Lawrenc et al., 2004; Losh \& Piven, 2006; Meyer \& Shean, 2006) as well as for Turkish speaking children. As was the case in the study carried out using the original form (Baron-Cohen et al., 2001a), the comparison carried out between genders has put forth a statistically significant difference in favor of girls.

Child participants were divided into three age groups in order to compare theory of mind scores based on age. 
It was determined that children in the first group (ages 6 - 8) displayed a lower performance in comparison with the children in the second group (ages 9 - 10) and the third group (11 years and above) in terms of the theory of mind development. This result shows similarities with the study results (Baron-Cohen et al., 2001b; Peterson \& Slaughter, 2009) putting forth that children can pass advanced theory of mind tests after 8 - 9 years of age. The fact that children aged nine and above were determined to be more successful in comparison to children in smaller age groups can be interpreted as an indication that Turkish children reached advanced theory of mind skills in the same period as children in other cultures.

\section{Conclusion}

The distinguishing feature of the Child Eyes Test between children with normal development and children with autism diagnosis can be interpreted as an indication that it can be used as an auxiliary tool in the diagnostic process. In addition, the Eyes Test can be used as an evaluation tool in planning social skills and it can also be used to determine the starting level of emotion teaching studies. In conclusion, it can be stated that the Turkish child form of the test can be used in the diagnostic and education processes as a valid and reliable test.

A sufficient number of individuals with autism could not be reached in this study, hence comparisons could not be made to adults with normal development. However, when the results of the study carried out on a Turkish sample group (Bora et al., 2005, 2008a \& 2008b; Yıldırım et al., 2011) is considered; it can be said that the Turkish form of the test can be used a valid tool to distinguish individuals with healthy/normal development and those with "social cognition" problems.

The socio-economic levels of the participants is middle level and above in both forms. Future studies can compare individuals from different socio-economic levels using larger participant groups. Another limitation of the study carried out using the adult form was that all of the participants had at least a high school education. This should be taken into account when interpreting the results. All of the participants are university students or university graduates who have not received any diagnosis. The properties of the study group should be considered when generalizing the results.

\section{References}

Atasoy, S. (2008). Yüksek Fonksiyonlu Otistik Çocuklarda Çeşitli Bilişsel Özelliklerin İncelenmesi. Yayınlanmamış Doktora Tezi, Ege Üniversitesi, Sosyal Bilimler Enstitüsü, İzmir.

Attwood, T. (2008). A Complete Guide to Asperger's Syndrome. Londra: Jessica Kingley Publishers.

Aydın, Ç., Avcı, G., Granti, T., Sefer, N., Yaşa, Y., \& Aksu-Koç, A. (2002). Which Linguistic Variables Promote the Development of Theory of Mind? Evidence from Turkish. Poster Presented at the Biennial Meetings of The Society for Research in Child Development, Tampa, FL.

Baron-Cohen, S., Leslie, A. M., \& Frith, U. (1985). Does the Autistic Child Have a “Theory of Mind?” Cognition, 21, 27-43. http://dx.doi.org/10.1016/0010-0277(85)90022-8

Baron-Cohen, S. (1995). Mindblindness: An Essay on Autism and Theory of Mind. Cambridge, MA: MIT Press/Bradford Books.

Baron-Cohen, S., Jolliffe, T., Mortimore, C., \& Robertson, M. (1997a). A Further Advanced Test of Theory of mind: Evidence from Very High Functioning Adults with Autism or Asperger Syndrome. Journal of Child Psychology and Psychiatry, 38, 813-822. http://dx.doi.org/10.1111/j.1469-7610.1997.tb01599.x

Baron-Cohen, S., Wheelwright, S., \& Jolliffe, T. (1997b). Is There a “Language of the Eyes”? Evidence from Normal Adults and Adults with Autism or Asperger Syndrome. Visual Cognition, 4, 311-331. http://dx.doi.org/10.1080/713756761

Baron-Cohen, S., Wheelwright, S., Hill, J., Raste, Y., \& Plumb, I. (2001a). The "Reading the Mind in the Eyes" Test Revised Version: A Study with Normal Adults, and Adults with Asperger Syndrome or High-Functioning Autism. Journal of Child Psychology and Psychiatry, 42, 241-251. http://dx.doi.org/10.1111/1469-7610.00715

Baron-Cohen, S. (2001). Theory of Mind and Autism: A Review. Special Issues of International Review of Research Mental Retardation, 23, 169-184 http://dx.doi.org/10.1016/S0074-7750(00)80010-5

Baron-Cohen, S., Wheelwright, S., Scahill, V., Lawson, J., \& Spong, A. (2001b). Are Intuitive Physics and Intuitive Psychology Independent? Journal of Developmental and Learning Disorders, 5, 47-78.

Bartsch, K., \& Wellman, H. M. (1995). Children Talk about the Mind. London: Oxford University Pres.

Bayramoğlu, M., \& Hohenberger, A. (2007). The Development of Theory of Mind in Turkish Preschoolers. The 13th European Conference on Developmental Psychology. 
Biehl, M., Matsumoto, D., Ekman, P., Hearn, V., Heider, K., Kudoh, T., \& Ton, V. (1997). Matsumoto and Ekman’s Japanese and Caucasian Facial Expression of Emotion (JACFEE): Reliability Data and Cross-National Differences. Journal of Nonverbal Behavior, 21, 3-21. http://dx.doi.org/10.1023/A:1024902500935

Bora, E., Gökçen, S., Kayahan, B., \& Veznedaroğlu, B. (2008a) Deficits of Social-Cognitive and Social-Perceptual Aspect of Theory of Mind in Remitted Patients with Schizophrenia. Effect of Residual Symptoms. The Journal Nervous and Mental Disease, 196, 95-99. http://dx.doi.org/10.1097/NMD.0b013e318162a9e1

Bora, E., Gökcen, S., \& Veznedaroğlu, B. (2008b) Empathic Abilities in People with Schizophrenia. Psychiatry Research, 160, 23-29. http://dx.doi.org/10.1016/j.psychres.2007.05.017

Bora, E., Vahip, S., Gonul, A. S., Akdeniz, F., Alkan, M., Ogut, M., \& Eryavuz, A. (2005) Evidence for Theory of Mind Deficits in Euthymic Patients with Bipolar Disorder. Acta Psychiatrica Scandinavica, 112,110-116. http://dx.doi.org/10.1111/j.1600-0447.2005.00570.x

Büyüköztürk, Ş., Kılıç-Çakmak, E., Akgün, Ö. E., Karadeniz, Ş., \& Demirel, F. (2008). Bilimsel Araştırma Yöntemleri. Ankara: Pegem Akademi.

Carroll, J. M., \& Yung, C. K. (2006). Sex and Discipline Differences in Empathising, Systemising and Autistic Symptomatology: Evidence from a Student Population. Journal of Autism and Developmental Disorders, 36, 949-957. http://dx.doi.org/10.1007/s10803-006-0127-9

Craig, J. S., Hatton, C., Craig, F. B., \& Bentall, R. P. (2004). Persecutory Beliefs, Attributions and Theory of Mind: Comparison of Patients with Paranoid Delusions, Asperger's Syndrome and Healthy Controls. Schizophrenia Research, 69, 2933. http://dx.doi.org/10.1016/S0920-9964(03)00154-3

Dziobek, I., Fleck, S., Kalbe, E., Rogers, K., Hassenstab, J., Brand, M., Kessler, J., Woike, J. K., Wolf, O. T., \& Convit, A. (2006). Introducing MASC: A Movie for the Assessment of Social Cognition. Journal of Autism and Developmental Disorders, 36, 623-636. http://dx.doi.org/10.1007/s10803-006-0107-0

Dziobek, I., Rogers, K., Fleck, S., Hassenstab, J., Gold, S., Wolf, O. T., \& Convit, A. (2005). In Search of "Master Mindreaders”: Are Psychics Superior in Reading the Language of the Eyes? Brain and Cognition, 58, 240-244. http://dx.doi.org/10.1016/j.bandc.2004.12.002

Domes, G., Heinrichs, M., Michel, A., Berger, C., \& Herpertz, S. C. (2007). Oxytocin Improves “Mind-Reading” in Humans. Biological Psychiatry, 61, 731-733. http://dx.doi.org/10.1016/j.biopsych.2006.07.015

Ekman, P. (1984). Expression and the Nature of Emotion. In K. R. Ç. Scherer, \& P. Ekman (Eds.), Approaches to Emotion (pp. 319-344). Hillsdale, NJ: Lawrence Erlbaum.

Ekman, P. (1994). Strong Evidence for Universals in Facial Expressions: A Reply to Russel’s Mistaken Critique. Psychological Bulletin, 115, 268-287. http://dx.doi.org/10.1037/0033-2909.115.2.268

Ekman, P., \& Friesen, W. V. (1986). A New Pan-Cultural Facial Expression of Emotion. Motivation \& Emotion, 10, $159-168$. http://dx.doi.org/10.1007/BF00992253

Flavell, J. H., Everett, B. A., Croft, K., \& Flavell, E. R. (1981). Young Children’s Knowledge about Visual Perception: Further Evidence for the Level 1 - Level 2 Distinction. Developmental Psychology, 17, 99-103. http://dx.doi.org/10.1037/0012-1649.17.1.99

Flavell J. H., \& Green, F. L. (1999). Development of Intuitions about the Controllability of Different Mental States. Cognitive Development, 14, 133-146. http://dx.doi.org/10.1016/S0885-2014(99)80021-5

Flobbe, L., Verbrugge, R., Hendriks, P., \& Krämer, I. (2008). Children’s Application of Theory of Mind in Reasoning and Language. Journal of Logic, Language and Information, 17, 417-442. http://dx.doi.org/10.1007/s10849-008-9064-7 http://www.springerlink.com/content/601101328q40k351/fulltext.pdf

Girli, A., Atasoy, S., \& Mutlu, B. (2003). Otistiklerin Değerlendirilmesinde Kullanılan PEP-R (Psiko-Eğitimsel Profil) Ölçeğinin Geçerlik Güvenirlik Çalışması. Gelişimsel Nöropsikiyatri Toplantıları I. Uluslararası Otizm Sempozyumunda sunulmuş bildiri, Istanbul.

Girli, A., \& Tekin, D. (2010a). Investigating False Belief Levels of Typically Developed Children and Children with Autism. Procedia-Social and Behavioral Sciences, 2, 1944-1950. http://dx.doi.org/10.1016/j.sbspro.2010.03.261

Girli, A., \& Tekin, D. (2010b). İleri Düzey Zihin Kuramı Testleri İle Otizmli ve Tipik Gelişim Gösteren Çocukların Zihin Kuramı Düzeylerinin İncelenmesi. 20. Özel Eğitim Kongresi'inde sunulmuş bildiri, Gaziantep.

Granti, T. (2004). The Relationship between Metacognitive Vocabulary and Theory of Mind Development. Unpublished Master's Thesis, Boğaziçi University, Istanbul.

Hale, C. M., \& Tager-Flusberg, H. (2005). Social Communication in Children with Autism: The Relationship between Theory of Mind and Discourse Development. Autism, 9, 157-178. http://dx.doi.org/10.1177/1362361305051395

Happé, F. G. E. (1994). An Advanced Test of Theory of Mind: Understanding of Story Characters’ Thoughts and Feelings by Able Autistic, Mentally Handicapped, and Normal Children and Adults. Journal of Autism and Developmental Disorders, 24, 129-154. http://dx.doi.org/10.1007/BF02172093 
Hallerbäck, M. U., Lugnegård, T., Hjärthag, F., \& Gillberge, C. (2009). The Reading the Mind in the Eyes Test: Test-Retest Reliability of a Swedish Version. Cognitive Neuropsychiatry, 14, 127-143. http://dx.doi.org/10.1080/13546800902901518

Harkness, K. L., Sabbagh, M. A., Jacobson, J. A., Chowdrey, N. K., \& Chen, T. (2005). Enhanced Accuracy of Mental State Decoding in Dysphoric College Students. Cognition and Emotion, 19, 999-1025. http://dx.doi.org/10.1080/02699930541000110

Howlin, P., Baron-Cohen, S., \& Hadwin, J. (1999). Teaching Children with Autism to Mind-Read: A Practical Guide. Chichester: John Wiley \& Sons.

Karasar, N. (1995). Bilimsel Araştırma Yöntemi. Ankara: Sim Matbaası.

Keçeli-Kaysılı, B., \& Acarlar, F. (2011). Zihin Kuramının 3-5 Yaşları Arasındaki Çocuklarda Gelişiminin Yanlış İnanç Performansina Göre İncelenmesi. Kuram ve Uygulamada Ĕ̈itim Bilimleri, 11, 1809-1826.

Kelemen, O., Erdélyi, R., Pataki, I., Benedek, G., Janka, Z., \& Kéri, S. (2005). Theory of Mind and Emotion Perception in Schizophrenia. Neuropsychology, 19, 494-500. http://dx.doi.org/10.1037/0894-4105.19.4.494

Kettle, J. W. L., O’Brien-Simpson, L., \& Allen, N. B. (2008). Impaired Theory of Mind in First-Episode Schizophrenia: Comparison with Community, University and Depressed Controls. Schizophrenia Research, 99, 96-102. http://dx.doi.org/10.1016/j.schres.2007.11.011

Kunihira, Y., Senju, A., Dairoku, H., Wakabayashi, A., \& Hasegawa, T. (2006). “Autistic” Traits in Non-Autistic Japanese Populations: Relationships with Personality Traits and Cognitive Ability. Journal of Autism and Developmental Disorders, 36, 553-566. http://dx.doi.org/10.1007/s10803-006-0094-1

Lawrence, E., Shaw, P., Baker, D., Baron-Cohen, S., \& David, A. (2004). Measuring Empathy: Reliability and Validity of the Empathy Quotient. Psychological Medicine, 34, 911-920. http://dx.doi.org/10.1017/S0033291703001624

Leslie, A. M. (1987). Pretense and Representation: The Origins of “Theory of Mind”. Psychological Review, 94, 412-426. http://dx.doi.org/10.1037/0033-295X.94.4.412

Leslie, A. M., \& Frith, U. (1988). Autistic Children's Understanding of Seeing, Knowing, and Believing. British Journal of Developmental Psychology, 6, 315-324. http://dx.doi.org/10.1111/j.2044-835X.1988.tb01104.X

Losh, M., \& Piven, J. (2006). Social-Cognition and the Broad Autism Phenotype: Identifying Genetically Meaningful Phenotypes. Journal of Child Psychology and Psychiatry, 48, 105-112. http://dx.doi.org/10.1111/j.1469-7610.2006.01594.x

Meltzoff, A. N., \& Moore, M. K. (1983). Newborn Infants Imitate Adult Facial Gestures. Child Development, 54, $702-709$. http://dx.doi.org/10.2307/1130058

Meyer, J., \& Shean, G. (2006). Social-Cognitive Functioning and Schizotypal Characteristics. Journal of Psychology: Interdisciplinary and Applied, 140, 199-207. http://dx.doi.org/10.3200/JRLP.140.3.199-207

Miller, C. A. (2006). Developmental Relationships between Language and Theory of Mind. American Journal of SpeechLanguage Pathology, 15, 142-154. http://dx.doi.org/10.1044/1058-0360(2006/014)

Murphy, D. (2006). Theory of Mind in Asperger's Syndrome, Schizophrenia and Personality Disordered Forensic Patients. Cognitive Neuropsychiatry, 11, 99-111. http://dx.doi.org/10.1080/13546800444000182

Ozonoff, S., Pennington, B., \& Rogers, S. (1991). Executive Function Deficits in High-Functioning Autistic Children: Relationship to Theory of Mind. Journal of Child Psychology and Psychiatry, 32, 1081-1106.

http://dx.doi.org/10.1111/j.1469-7610.1991.tb00351.x

Ozonoff, S., Rogers, S., \& Pennington, B. (1991). Asperger's Syndrome: Evidence of an Empirical Distinction from HighFunctioning Autism. Journal of Child Psychiatry and Psychology, 32, 1107-1122. http://dx.doi.org/10.1111/j.1469-7610.1991.tb00352.x

Özdamar, K. (1999). Paket Programlar İle İstatistiksel Veri Analizi. Eskişehir: Kaan Kitapevi.

Perner, J., \& Wimmer, H. (1985). “John Thinks That Mary Thinks That...”Attribution of Second-Order Beliefs by 5- to 10Year-Old Children. Journal of Experimental Child Psychology, 39, 437-471. http://dx.doi.org/10.1016/0022-0965(85)90051-7

Perner, J., Leekam, S. R., \& Wimmer, H. (1987). Three-Year-Olds’ Difficulty with False Belief: The Case for a Conceptual Deficit. British Journal of Developmental Psychology, 5, 125-137. http://dx.doi.org/10.1111/j.2044-835X.1987.tb01048.x

Perner, J., Frith, U., Leslie, A. M., \& Leekan, S. R. (1989). Exploration of the Autistic Child's Theory of Mind: Knowledge, Belief, and Communication. Child Development, 60, 689-700. http://dx.doi.org/10.2307/1130734

Peterson, C. C., \& Slaughter, V. (2009). Theory of Mind (ToM) in Children with Autism or Typical Development: Links between Eye-Reading and False Belief Understanding. Research in Autism Spectrum Disorders, 3, 462-473. http://dx.doi.org/10.1016/j.rasd.2008.09.007

Premack, D., \& Woodruff, G. (1978). Does the Chimpanzee Have a Theory of Mind? Behavioural and Brain Sciences, 1, 515-526. http://dx.doi.org/10.1017/S0140525X00076512 
Gerrig, R. J., \& Zimbardo, P. G. (2012). Psikoloji ve Yaşam [Psychology and Life] (Çev: G. Sart). Ankara: Nobel Yayınları.

Scaife, M., \& Bruner, J. S. (1975). The Capacity for Joint Visual Attention in the Infant. Nature, 253, 265-266. http://dx.doi.org/10.1038/253265a0

Schopler, E., Reichler, R. J., Bashford, A., Lansing, M., \& Marcus, L. (1990). Individualized Assessment and Treatment for Autistic and Developmentally Disabled Children: Vol. 1 Psychoeducational Profile-Revised (PEP-R). Austin, TX: Pro-ed.

Tager-Flusberg, H. (1993). What Language Reveals about the Understanding of Minds in Children with Autism. In S. BaronCohen, H. Tager-Flusberg, \& D. Cohen (Eds.), Understanding Other Minds: Perspectives from Autism (pp: 138-157). Oxford: Oxford University Press.

Voracek, M., \& Dressler, S. G. (2006). Lack of Correlation between Digit Ratio (2D:4D) and Baron Cohen's "Reading the Mind in the Eyes" Test, Empathy, Systemising, and Autism-Spectrum Quotients in a General Population Sample. Personality and Individual Differences, 41, 1481-1491. http://dx.doi.org/10.1016/j.paid.2006.06.009

Watson, A. C., Nixon, C. L., Wilson, A., \& Capage, L. (1999). Social Interaction Skills and Theory of Mind in Young Children. Developmental Psychology, 35, 386-391. http://dx.doi.org/10.1037/0012-1649.35.2.386

Wellman, H. M. (1990). The Child's Theory of Mind. Cambridge, MA: Bradford.

Wellman, H. M., Cross, D., \& Watson, J. (2001). Meta-Analysis of Theory of Mind Development: The Truth about False Belief. Child Development, 72, 655-684.

Wellman, H. M., Phillips, A. T., \& Rodriguez, T. (2000). Young Children’s Understanding of Perception, Desire, and Emotion. Child Development, 71, 895-912. http://dx.doi.org/10.1111/1467-8624.00198

Wimmer, H., \& Perner, J. (1983). Beliefs about Beliefs: Representation and Constraining Function of Wrong Beliefs in Young Children's Understanding of Deception. Cognition, 13, 103-128. http://dx.doi.org/10.1016/0010-0277(83)90004-5

Yağmurlu, B., Berument, S. K., \& Çelimli, Ş. (2005). The Role of Institution and Home Contexts in Theory of Mind Development. Journal of Applied Developmental Psychology: Special Issue on Child Abandonment, 26, 521-537.

Yıldırım, E. A., Kaşar, M., Güdük, M., Ateş, E., Küçükparlak, İ., \& Özalmete, E. O. (2011). Gözlerden Zihin Okuma Testi'nin Türkçe Güvenirlik Çalışması. Türk Psikiyatri Dergisi, 22, 177-186. 
Scientific Research Publishing (SCIRP) is one of the largest Open Access journal publishers. It is currently publishing more than 200 open access, online, peer-reviewed journals covering a wide range of academic disciplines. SCIRP serves the worldwide academic communities and contributes to the progress and application of science with its publication.

Other selected journals from SCIRP are listed as below. Submit your manuscript to us via either submit@scirp.org or Online Submission Portal.
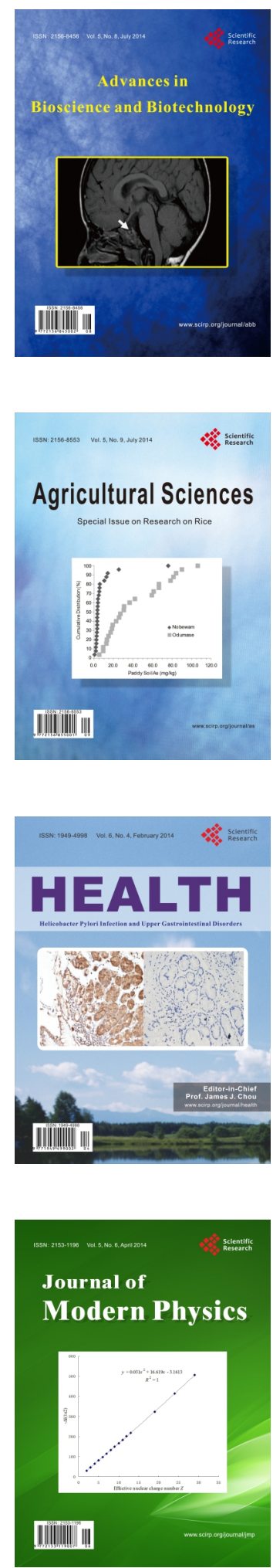
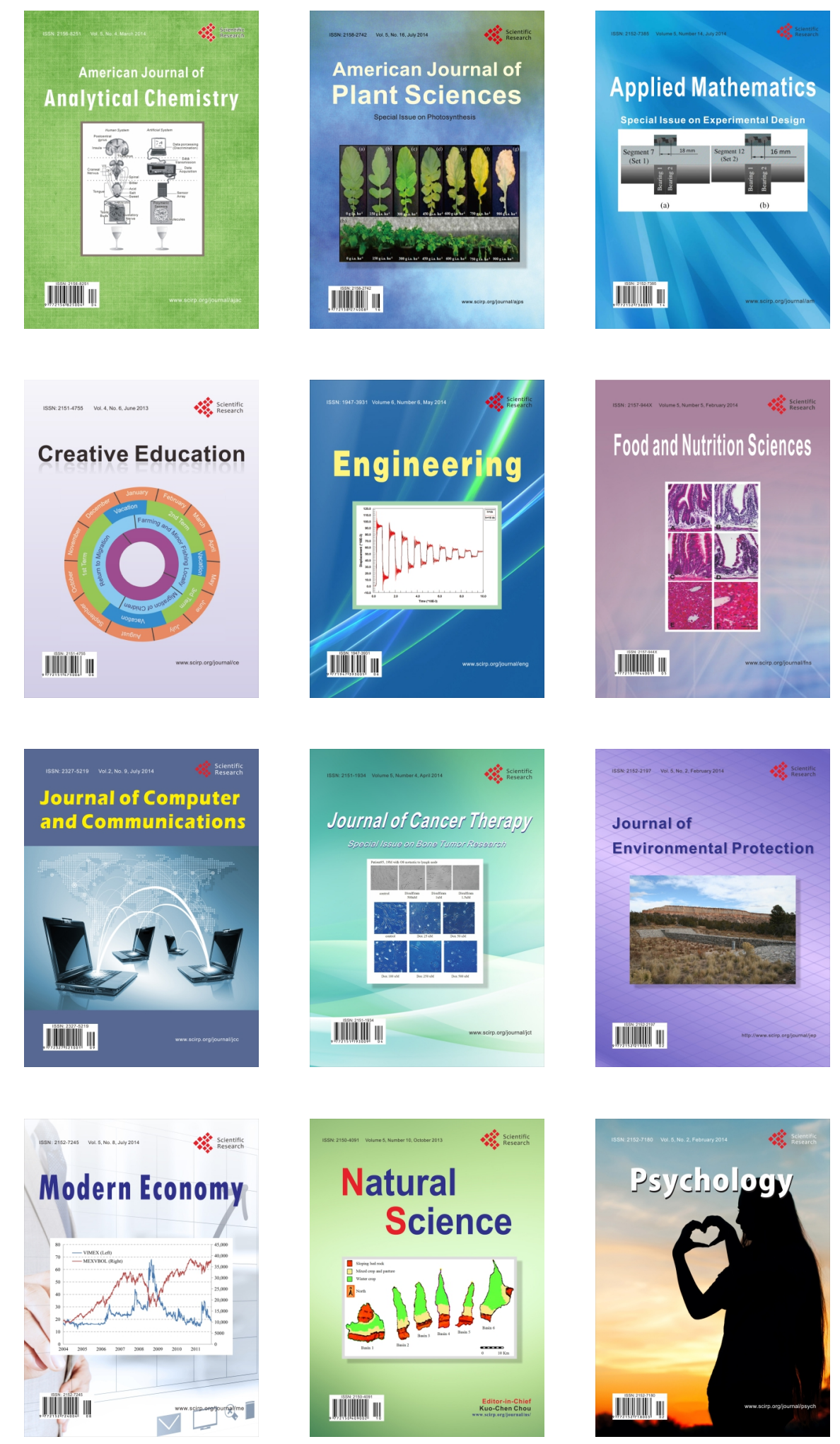